\title{
O Terremoto de Lisboa
}

\author{
[Erdbeben von Lissabon]
}

Walter Benjamin

Vocês já tiveram de esperar alguma vez pelo farmacêutico e observaram como ele faz a receita? Em uma balança com pesos totalmente leves, ele pesa grama por grama ou décimo por décimo todas as matérias e pozinhos que compõem o pó pronto. Assim como com o farmacêutico, acontece isso comigo, se eu narrar algo a vocês na hora do rádio. Meus pesos são os minutos e eu preciso medir exatamente quanto disso, quanto daquilo, para que a mistura se torne também correta.

- Ora essa, vocês aí dirão: como assim? Se você quiser contar sobre o terremoto de Lisboa, então, comece [a narrar] como ele começou; e, então, continue a contar o que aconteceu. Todavia, se eu assim o fizesse, não acredito que isso teria graça pra vocês. Uma casa após a outra desaba, uma família após a outra morre; os sustos do fogo se propagando e os sustos da água, a escuridão e os saques e o lamento dos atingidos e as queixas daqueles que estão à procura por seus parentes - ouvir isto e nada mais do que isto, não seria agradável a ninguém e precisamente isto também são as coisas que, mais ou menos as mesmas, estão presentes em todas as grandes catástrofes naturais.

Contudo, o terremoto que arruinou Lisboa em $1^{\circ}$ de novembro de 1755 não foi só um infortúnio como mil outros, e sim, dentre muitos, único e estranho. E disto, o que ele foi, quero lhes contar. Em primeiro lugar, ele foi com certeza um dos maiores e mais devastadores que já existiu. Mas ele não só provocou e ocupou o mundo inteiro como poucas coisas naquele século. A destruição de Lisboa foi à época, da mesma maneira como seria hoje a destruição de Chicago ou de Londres. Por volta da metade do século XVIII Portugal ainda estava no auge do seu violento poder colonial. Lisboa era uma das cidades de negócio mais ricas da Terra; seu porto na foz do Tejo, saía ano, entrava ano, estava cheio de embarcações, e abainhado por casas comerciais de ingleses, franceses, alemães, sobretudo por mercadores de Hamburgo. A cidade contava com 30.000 casas e mais de 250.000 habitantes, dos quais mais ou menos um quarto morreu nesse terremoto.

A corte do rei era famosa por seu rigor e sua pompa e, em muitas descrições que apareceram anos antes do terremoto na cidade de Lisboa, pode-se ler as coisas mais raras da solenidade cerimoniosa, com a qual, nas 
noites de verão, na praça principal da cidade, a Praça do Rocio, os cortesãos e suas famílias se tratavam em suas carroças e, sem descer de seus carros, conversavam um bocado uns com os outros. Do rei de Portugal tinha-se então uma idéia absolutamente tão superior, que um dos muitos folhetos, que divulgavam por toda Europa descrições exatas da desgraça, sequer conseguiu noticiar que um rei tão grandioso tivesse sido atingido.

- "Como a desgraça", assim escreve esse raro jornalista, "aparece então em sua grandeza apenas quando o terremoto está terminado, assim, todos podem ter uma idéia, a mais lamentável desse horrível caso, quando se pondera $o$ fato de que um grande rei com sua esposa ficaram abandonados por todos os homens dentro de uma carroça, durante um dia inteiro, nas mais deploráveis condições."

Os folhetos, nos quais se lê a mesma coisa, representavam na época a posição dos jornais. Das testemunhas oculares conseguiu-se, quem isso pôde, relatos provavelmente completos que, então, permitiu imprimir-se e vender. E a partir de um tal relato, tal como ele se originou na época - com base nas vivências [Erlebnisse] de um inglês radicado em Lisboa - quero contar-lhes uma coisa a seguir.

Posto que esse acontecimento agitou as pessoas tão enormemente, que numerosos folhetos sobre ele passaram de mão em mão, e que mesmo quase 100 anos depois novos relatos apareciam, isto então tem ainda um motivo especial. Esse terremoto, isto é, em suas conseqüências, foi o mais abrangente que jamais se ouviu falar.

Por toda Europa até a África ele foi sentido e calculava-se que atingiu, com seu mais afastado prolongamento, a superfície monstruosa de dois milhões e meio de quilômetros quadrados. Os mais fortes abalos atingiram a costa do Marrocos, por um lado, e a costa da Andaluzia e da França, por outro. As cidades de Cádiz, Jerez e Algeciras foram quase completamente arruinadas. Em Sevilha, as torres da catedral tremeram como junco no vento diante de testemunhas oculares. Os mais violentos abalos, todavia, propagaram-se pelo mar. Da Finlândia até as Índias Holandesas percebeu-se o violento movimento das águas e calcula-se que o abalo do oceano da costa portuguesa se propagou até a foz do Elba com enorme rapidez, em aproximadamente um quarto de hora, tanto quanto o que foi sentido no mesmo espaço de tempo com o infortúnio.

Mas, mais do que isso, a fantasia ocupou os homens antigos; o que nas semanas anteriores foi observado em acontecimentos naturais raros foi então considerado posteriormente - e nem sempre sem razão - como presságio do futuro infortúnio. Assim, duas semanas antes do dia da desgraça, por uma vez em Locarno, no sul da Suíça, saíram da Terra 
vapores que em duas horas tinham se transformado em uma névoa vermelha, caindo à noite como uma chuva de púrpura. A partir disso, pôdese observar na Europa ocidental terríveis furacões ligados a chuvas torrenciais e inundações. Oito dias antes do abalo, a Terra em Cádiz estava coberta por uma grande quantidade de vermes.

Ninguém mais se ocupou com esses estranhos acontecimentos do que o grande filósofo alemão Kant, sobre quem alguns de vocês talvez já ouviram falar pelo menos uma vez. Na época em que o terremoto aconteceu, ele era um jovem de $24 \operatorname{anos}^{4}$ e jamais, nem antes nem depois, saiu de Königsberg, sua terra natal, mas com um enorme afã reuniu todas as notícias que podia receber sobre esse terremoto, e um pequeno texto que ele escreveu sobre isso foi sem dúvida o início da Geografia científica na Alemanha. Com certeza o início da Sismologia.

$\mathrm{Eu}$ lhes contaria com o maior prazer alguma coisa sobre o caminho que essa ciência percorreu desde aquela descrição do terremoto de 1755 até os dias de hoje. Mas eu preciso ser cauteloso, para que o nosso inglês cuja descrição de suas vivências junto ao terremoto eu quero lhes apresentar - não se veja completamente metido em apuros. Ele espera já impaciente, pois, após 150 anos, em que ninguém tratou dele, ele quer falar novamente, e me permite dizer a vocês algumas palavras disso que sabemos sobre o terremoto.

Em primeiro lugar, a coisa não é como vocês a imaginam. Pois eu aposto que se eu pudesse fazer agora uma pequena pausa e lhes perguntar como vocês tentariam esclarecer um terremoto, vocês pensariam primeiramente nos vulcões. Realmente as erupções vulcânicas estão mesmo ligadas frequentemente a terremotos ou foram pelo menos anunciadas por eles. Assim também, durante 2000 anos - dos gregos a Kant e ainda até mais ou menos por volta dos anos de 1870 - as pessoas acreditavam que os terremotos viessem dos gases e vapores fogosos no interior da Terra e de coisas parecidas.

\footnotetext{
${ }^{4} \mathrm{Na}$ realidade, Kant estava com 31 anos quando o terremoto de Lisboa aconteceu. Assim, trata-se ou de um erro editorial, ou de uma pequena confusão por parte de Benjamin, talvez por conta do ano de nascimento de Kant, 1724. Todavia, o que se nos apresenta de maneira mais relevante é o fato de tal acontecimento ter despertado em Kant a necessidade de um aprofundamento no conhecimento do mundo físico. Ou seria mera coincidência o fato de ele ter publicado três artigos sobre abalos terrestres e ter oferecido pela primeira vez o curso de Geografia física na Universidade de Königsberg um ano após o acontecido em Lisboa, e de ter esboçado o seu primeiro projeto de constituição de uma ciência propedêutica do mundo dois anos após esse evento? [N.T.]
} 
Mas então, quando se examinou, com instrumentos de medição e com cálculos da coisa, cuja acuidade e refinamento vocês não podem sequer imaginar, e das quais também eu quase nem imagino, enfim, quando se examinou a coisa, resultou algo completamente diferente, de qualquer modo, do grande terremoto que foi o de Lisboa. Eles não se originam do interior mais profundo da Terra, que se imagina também hoje líquido ou, melhor dizendo, lamacento, como uma lama de fogo, e sim por meio dos processos na crosta terrestre. A crosta terrestre é uma camada de aproximadamente $3000 \mathrm{~km}$ de espessura. Nessa camada, a agitação é contínua; permanentemente as massas deslocam-se dentro dela, por onde elas sempre tentam novamente chegar, umas com as outras, num equilíbrio. Conhecemos alguns dos motivos que atrapalham esse equilíbrio; outros estamos prestes a pesquisar no trabalho incessante. Tanto quanto esteja certo que as mais importantes transformações acontecem por meio do resfriamento incessante da Terra, através disso originam-se, então, tensões nas massas rochosas, sob cuja influência, essas são finalmente rompidas e, numa acomodação que nós sentimos como terremoto, procuram um novo equilíbrio. Outras transformações acontecem através da erosão das montanhas que, portanto, ficam mais leves, e através dos assoreamentos do solo dos mares, que fica mais pesado. Tempestades, que antes de qualquer coisa zunem no outono por toda a Terra, abalam, por seu lado, sua superfície, e finalmente pode ser constatado com isso quais forças, através da atração dos corpos estranhos, são exercidas na superfície terrestre. Mas se vocês nunca mais pudessem ficar em repouso, então, teria mesmo de haver terremoto constantemente. Vocês têm razão, ele é assim. Os instrumentos enormemente refinados nunca estão parados, isso quer dizer: a Terra treme sempre, só que na maioria das vezes nós não sentimos nada disso.

Pior ainda, quando vem de repente do céu sereno - isso pode ser tomado inteiramente de maneira literal. - "Pois", assim escreve nosso inglês que finalmente agora diz "o sol parecia em seu esplendor. O céu estava completamente puro e claro, e não se sentia o mais insignificante indício de qualquer acontecimento da natureza quando, entre 9 e 10 horas da manhã, eu estava sentado na escrivaninha, minha mesa sofreu um movimento que me surpreendeu bastante e eu não reconheci aí nenhuma causa. Ao mesmo tempo que eu, de algum modo, ainda refletia sobre a causa, a casa tremeu de cima a baixo. Sob a Terra tremeu um trovão, como se se descarregasse uma trovejada a grande distância. Aí então eu larguei rapidamente a pena e levantei-me num salto. O perigo era grande, restou mesmo a esperança de que a coisa fosse correr sem dano; somente o próximo momento terminou com a dúvida. Deixou-se ouvir uma crepitação terrível, como se todos os edifícios na cidade desmoronassem. Também 
minha casa foi tão abalada, que os andares de cima imediatamente desabaram, e os quartos, nos quais eu morava, balançaram tanto que toda a aparelhagem caiu. Eu esperava a cada momento ser fulminado, pois os muros rachavam e das fendas precipitavam grandes pedras para fora, enquanto as sustentações do telhado por toda a parte quase flutuavam ao ar livre. Nesse momento o céu se escureceu tanto, que não se podia mais reconhecer nenhum objeto. Uma tempestade de areia, ou em conseqüência do pó incomensurável que as casas desabando provocavam, ou porque se desenvolveram uma grande quantidade de vapores sulfúreos da Terra. Finalmente, a noite clareou de novo, a violência dos abalos se acalmou; eu me acalmei e dei uma olhada em todas as direções. A mim ficou claro que eu até aquele momento devia a minha vida a uma pequena coincidência. Se eu estivesse vestido, eu teria com certeza fugido imediatamente para a rua e teria sido fulminado pelos edifícios desabando. Vesti rapidamente roupa e calçado, e então me lancei na rua, para além do cemitério São Paulo, em cuja altitude eu acreditava estar o mais seguro. Ninguém estava em condições ainda de reconhecer a rua onde morava; muitos não sabiam dar sequer alguma resposta de como aquilo tinha lhes acontecido; tudo estava destruído e ninguém sabia onde o seu ou os seus se encontravam. À altura do cemitério eu fui, pois, testemunha de um horrível espetáculo: tanto quanto a visão podia varrer o mar, vagueavam uma quantidade de barcos e chocavam-se uns com os outros, como se a tempestade mais forte se desencadeasse furiosamente. De uma só vez, o poderoso cais afundou na margem e todos os homens que nele acreditaram estar seguros. Os barcos e veículos nos quais buscavam tanto salvamento, foram ao mesmo tempo uma vítima do mar." Isso ocorreu, como se sabe de outros relatos, aproximadamente uma hora após o segundo e mais devastador abalo terrestre, quando aquela monstruosa onda de água de $20 \mathrm{~m}$ de altura, que o inglês viu de longe, quebrou na cidade. Quando a onda recuou, de repente o leito do Tejo apareceu completamente seco; seu recuo foi tão violento, que arrastou toda a água do rio. "Quando a noite", assim encerra o inglês, "deixou-se cair na cidade despovoada, parecia torná-la inteiramente um mar de fogo: estava tão claro, que se podia ler uma carta. Em 100 lugares, no mínimo, as chamas subiam, desencadeando-se durante seis dias. O que o terremoto tinha poupado, elas consumiram. Petrificados de dor, milhares olhavam fixamente para elas, enquanto que mulheres $\mathrm{e}$ crianças suplicavam por ajuda a todos os santos e anjos. A Terra tremeu continuamente pelo mesmo tempo, mais ou menos, com freqüência de um quarto de hora, ininterruptamente"

Tudo isso, nesse dia de desgraça, $1^{\circ}$ de novembro de 1755 . O infortúnio que ele trouxe, é um dos pouquíssimos que a humanidade ainda hoje tão sem poder encara como há 170 anos. Contudo, também aqui a 
técnica encontrará meios, ainda que também apenas indiretamente, para a previsão. Até o momento, segundo parece, os órgãos dos sentidos de alguns animais são superiores aos nossos instrumentos mais apurados. Especialmente cachorros podem mostrar uma intranqüilidade tão irreconhecível já dias antes do desencadeamento do terremoto, que se os utiliza em regiões perigosas como ajudantes à espera de terremotos. Com isso encerram-se meus 20 minutos e eu espero que eles não tenham sido longos pra vocês. 